\title{
Living During a Technological Revolution
}

\author{
Barbara J. Thayer-Bacon ${ }^{1}$
}

Published online: 20 September 2019

(c) Springer Nature B.V. 2019

\section{Introduction}

In my "Philosophy of Education: Theory Writing" course I start the semester with a onepage essay John Dewey wrote in 1935 titled, "The Teacher and His World," published in The Social Frontier. In that essay Dewey argues that we live in conflicting times and he gives three examples to illustrate the conflicts: (1) between an economy of scarcity and abundance, with banks congested with money while factories are closed and millions are unemployed; (2) between private and public aims, with President Hoover's belief in rugged individualism and his support of social policies during the depression; and (3) between the largest number of students receiving an education at the highest level, due to an increase in the number of high schools and colleges giving more students access to higher education, while they are unable to find jobs to use the training they have received. Dewey's central claim is that teachers have some responsibility in putting our inconsistent times right.

When we read this essay in fall, 2016, during the USA's presidential election, it was striking to realize how similar our current conflicting times are with what Dewey described in 1935. Again, in the USA we have an economy where there is a significant gap between the top $1 \%$ of Americans in terms of wealth, versus the rest of us. We have more young adults with higher education levels than ever before, and more of them shouldered with significant debt as a result, and struggling to find jobs. We have a Democratic party standing for more policies that offer social support (e.g. government paid health care and college education, with the slogan "Stronger Together"), while the Republican party stands for closing our borders to immigrants and building walls at our borders to help address safety issues and loss of jobs that have been out-sourced to other countries ("America First").

The conflicts in the USA election of 2016 were echoed in the United Kingdom's Brexit vote, and in the Netherland's and France's presidential elections. The tensions exist in other countries as well such as Spain, Italy, Greece, Japan, and Germany. Around the world, we have problems with high unemployment rates, especially for young adults, even with higher education levels, and we have high rates of migration, as people try to find work beyond their country's borders in this global economy.

Martin (1992) points out in The Schoolhome that when the Deweys were developing their University Elementary School in Chicago (in 1896), which was renamed as the Laboratory School in 1902, the USA was going through the industrial revolution, and

Barbara J. Thayer-Bacon

bthayer@utk.edu

1 University of Tennessee, Knoxville, USA 
work was changing as more workers left their farms and cottage industries for factory jobs in the cities. Dewey (1935) argued that because we were living in significantly changing times, the industrial revolution, we needed to rethink our school structures, curriculum, and pedagogy, to meet the needs of those changing times. Schools must take up the task of teaching skills that before were being taught at home, such as weaving and carpentry (vocational skills of his time period). In the 1990's, Martin (1992) describes the USA as going through a second significant social change, with both parents joining the public work force, and she argues that we need to rethink our school structures, curriculum, and pedagogy again. Whereas parents (and extended family members) used to be the "silent partners" with teachers in schools, and much informal education occurred in the home such as the teaching of cooking, cleaning, responsibility, and manners; few parents are home anymore. Therefore, schools need to embrace the need to include the domestic curriculum in our public school spaces, what Martin called the "3 C's" of care, concern, and connection.

In looking back from a perspective that is twenty-five plus years after The Schoolhome (Martin 1992), we can see that our society has adjusted to the need for child care with both parents working in the public world, and a significantly greater number of day cares and preschool programs exist for young, preschool age children, as well as extended care programs before and after school for school age children. Care work that before parents and extended family members were doing is now a source of employment for early childhood educators, to help take care of the needs of a changing work force. However, today we seem to be in another social revolution, as work is changing significantly again, due to advances in technology. Let's call these current changes in work the technology revolution.

Just as Dewey argued during the industrial revolution, from the 1890's-1930's, and Martin argued in the 1960's-1990's with our "second wave" working revolution (when middle class women joined the work force in significant numbers): the times are out of joint, potentially dangerous conflicts exist, and teachers have some responsibility in making things right. Again, we need to rethink our school structures, curriculum, and pedagogy. In an effort to contribute to that process, I made an invitation in 2017 for some scholars from around the world to re/examine the connections between work and education, and add their voices to the conversation. The results are what is found in this special issue. The essays are published as they were sent to me, unfiltered, so that they could be published in a timely manner, as I feel an urgency to this theme. I hope that after reading these essays, others will want to contribute their perspectives as well, and will add their voices to the conversation.

The special issue begins with the essay I wrote and sent to the invited authors, to start the discussion. It is titled, "Redefining work and education in the Technological Revolution.” Alexander Sidorkin, California State University at Sacramento, uses Baumol's cost disease to explain the rising cost in education without corresponding increase in productivity and the theory of Trinity developed by early Christian philosophers to construct a framework for a cultural shift where relationality becomes the end while learning is a means of education in his "Baumol's cost disease and the Trinitarian pedagogy."

Mario Di Paolantonio, York University, explores what role might education have in Berardi's musings in his "The malaise of the soul at work: The drive for creativity, self-actualization, and curiosity in education." He draws on Berardi's ideas to critically appraise the seemingly-benign aspirations of the "creative class," a term coined to signal a new era for human flourishing afforded by shifts toward personal creativity in the digital economy. He considers how education tends to replicate a form of learning that puts the soul to work, promoting a narrow, self-enterprising subject with a frantic instrumental orientation towards the world. He concludes with a discussion of how demands on learners lead to the diseases of the soul. 
Liz Jackson, University of Hong Kong, seeks to shed light on how ordinary people learn in ways and through means that are at odds with the experiences of scholars and elites in her "Mediating class: The role of education and competing technologies in social mobilization." Jackson considers how online media is marked by private control of information, and then provides a theoretical understanding of the relationship between technology and education and the linkages of class and media consumption. She integrates these topics by exploring how online learning through segmented social media operates to reproduce class and facilitate and mobilize sectarianism.

Zaha Alsuwailan, Kuwait University, turns to a discussion of the role of the state in forming and distributing well-being in her "Work and social justice: The demands of welfare in Kuwaiti society." Using Kuwait as an example of a welfare state, which ideally protects and promotes the economic and social well-being of its citizens, she argues for the need for equal and just welfare state reform based on current needs and demands of both society and the labor market. She discusses unemployment as a result of disequilibrium between society and market needs, then proposes education reform as a solution to the unemployment problem.

Three authors from Finland, Katarlina Taiinen, Anniina Leivskä, and Kristiina Brunila, University of Helsinki, submitted a paper during this time period that fit in so well with the special issue theme, that I asked them if we could include them in the conversation. Their essay, "Democratic education for hope: Contesting the neoliberal common sense," provides a reinterpretation of Paulo Freire's philosophy of hope that aims to contest the prevailing neoliberal "common sense." The paper constructs three principles for democratic education - 'history as possibility', 'the ethics of intervention,' and 'democratization' - which are intended to function as a foundation for democratic education through which the virtue of hope can be fostered. These principles are argued to form a basis for reviving the political dimensions of education and thus allowing collective transformative action.

Gert Biesta, National University of Ireland, gets the last word in this special issue with his essay, "What kind of society does the school need? Redefining the democratic work of education in impatient times." Biesta sets the context of the modern school as under a relentless pressure to perform in a global rat-race. The modern school is increasingly seen as a problem, with high levels of dissatisfaction amongst teachers, students, politicians, the media, and the public at large, who all want something better from the school, although they disagree about what this may look like. He asks: is it time to give up on the modern school and hand it over to educational capitalists, or should we try again? If so, where might we go? The reflections Biesta offers in his paper are primarily meant to think again about the relationship between the school and society, arguing for a more 'obstinate' school and a more 'patient' society.

It is our sincere hope to trigger more conversation amongst others, authors and readers of Studies in Philosophy and Education, during the very tumultuous times we are living. Some might even call these times revolutionary, a technological revolution with potentially dangerous consequences for our internationally connected world.

\section{References}

Dewey, J. 1935. The teacher and his world. The Social Frontier 1(4): 7.

Martin, J.R. 1992. The schoolhome. Cambridge, MA: Harvard University Press.

Publisher's Note Springer Nature remains neutral with regard to jurisdictional claims in published maps and institutional affiliations. 